\title{
Short-term and long-term antibody response by mice after immunization against Neisseria meningitidis B or diphtheria toxoid
}

\author{
G.P. Silva, S.C. Cruz, A.C. Cruz and L.G. Milagres \\ Departamento de Microbiologia, Imunologia e Parasitologia, Faculdade de Ciências Médicas, \\ Universidade do Estado do Rio de Janeiro, Rio de Janeiro, RJ, Brasil
}

\begin{abstract}
Serogroup B Neisseria meningitidis (MenB) is a major cause of invasive disease in early childhood worldwide. The only MenB vaccine available in Brazil was produced in Cuba and has shown unsatisfactory efficacy when used to immunize millions of children in Brazil. In the present study, we compared the specific functional antibody responses evoked by the Cuban MenB vaccine with a standard vaccine against diphtheria (DTP: diphtheria, tetanus, pertussis) after primary immunization and boosting of mice. The peak of bactericidal and opsonic antibody titers to MenB and of neutralizing antibodies to diphtheria toxoid (DT) was reached after triple immunization with the MenB vaccine or DTP vaccine, respectively. However, 4 months after immunization, protective DT antibody levels were present in all DTP-vaccinated mice but in only $20 \%$ of the mice immunized against MenB. After 6 months of primary immunization, about $70 \%$ of animals still had protective neutralizing DT antibodies, but none had significant bactericidal antibodies to MenB. The booster doses of DTP or MenB vaccines produced a significant antibody recall response, suggesting that both vaccines were able to generate and maintain memory $B$ cells during the period studied (6 months post-triple immunization). Therefore, due to the short duration of serological memory induced by the MenB vaccine (VA-MENGOC-BC ${ }^{\circledast}$ vaccine), its use should be restricted to outbreaks of meningococcal disease.
\end{abstract}

Key words: Serological memory; Antibody recall response; Booster immunization

\section{Introduction}

In the absence of an effective vaccine, serogroup $B$ Neisseria meningitidis (MenB) remains a major cause of invasive disease in early childhood in developed countries (1). In Brazil about 3500 cases of meningococcal disease are reported annually, with an average incidence of 2 cases/100,000 inhabitants and a case-fatality rate of $20 \%$. The main serogroups circulating are $\mathrm{B}$ and $\mathrm{C}$, with $\mathrm{a}$ progressive increase of serogroup $C$ since the 1990s (2).

A multicomponent MenB vaccine $(4 \mathrm{CMenB})$ containing outer membrane vesicles from the New Zealand strain together with 3 recombinant proteins, Neisserial adhesin $\mathrm{A}$, factor $\mathrm{H}$ binding protein and Neisserial heparin binding antigen, has been recently developed (1). However, the Cuban vaccine, VA-MENGOC-BC ${ }^{\circledR}$, is the only MenB vaccine commercially available in Brazil but it showed no efficacy in young children (3). An important limitation of the current MenB outer membrane vesicle (OMV) vaccines is the short duration of both antibody response and protective efficacy $(4,5)$. The goal of the present study was to investigate the duration of murine functional antibodies to MenB after primary immunization (three injections of vaccine) and the effect of a booster dose administered at 2, 4, and 6 months post-third immunization. For comparison with an effective vaccine that induces long-lasting antibody response, we used the diphtheria, tetanus, pertussis (DTP) vaccine, which is routinely used by public health authorities to immunize children.

Correspondence: L.G. Milagres, Departamento de Microbiologia, Imunologia e Parasitologia, Faculdade de Ciências Médicas, Universidade do Estado do Rio de Janeiro, Av. Professor Manoel de Abreu, 444, 3으 andar, 20550-170 Rio de Janeiro, RJ, Brasil. Fax: +55-21-2868-8376. E-mail: lucimar@uerj.br and/or milagreslucimar@gmail.com

The current address of S.C. Cruz is Serviço de Integração de Atividades Laboratoriais, Instituto de Pesquisa Clínica Evandro Chagas, Fundação Oswaldo Cruz, Rio de Janeiro, RJ, Brasil. 


\section{Material and Methods}

\section{Serogroup B meningococcal strain}

The Cuban vaccine strain (Cu385/83) of serotype:serosubtype:immunotype 4,7:P1.19,15:L3,7,9 was used for the preparation of OMVs to be used in the opsonic assay and as the target strain for the bactericidal assay. H355/75 (B:15:P1.19,15:L3,7,9,8) and its variants PorA ${ }^{-}$and Opa $^{-}$ were also used for the bactericidal and opsonic antibody assays. The origin of these strains and the preparation of OMVs have been previously described (6)

\section{Vaccine and immunization}

The experiments described below were performed according to the guidelines of the "Colégio Brasileiro de Experimentação Animal" and were approved by the Ethics Committee for the Care and Use of Experimental Animals (CEUA) of Instituto de Biologia Roberto Alcântara Gomes, Universidade do Estado do Rio de Janeiro (Protocol No. CEUA/038/2010).

The VA-MENGOC-BC ${ }^{\circledR}$ (Finlay Institute, Habana, Cuba) and DTP (Instituto Butantan, São Paulo, SP, Brazil) vaccines were obtained commercially. Five- to 6week-old female Swiss mice were immunized with 3 intramuscular injections of MenB or DTP vaccine over a period of 2 weeks.

Each MenB vaccine injection $(100 \mu \mathrm{L})$ contained $2 \mu \mathrm{g}$ ( $1 / 25$ of the human dose) of outer membrane proteins, $2 \mu \mathrm{g}$ $\mathrm{C}$ polysaccharide, $400 \mu \mathrm{g} \mathrm{Al}(\mathrm{OH})_{3}$ and $50 \mu \mathrm{g}$ thimerosal as preservative. The DTP vaccine injection $(100 \mu \mathrm{L})$ contained $2 \mu \mathrm{g}$ diphtheria toxoid (1/13 of the human dose), $2 \mu \mathrm{g}$ tetanus toxoid, $28 \mathrm{OP} / \mathrm{mL}$ whole cells of Bordetella pertussis, $500 \mu \mathrm{g} \mathrm{Al}(\mathrm{OH})_{3}$ and $80 \mu \mathrm{g}$ thimerosal.

Serum samples were obtained from a group of mice before and 14 days after each injection of vaccine during the primary immunization schedule (total of 3 injections) and at 2, 4, and 6 months after the third dose (pre-booster sera). Blood was collected 14 days after the booster dose was given to different groups of mice at 2, 4, and 6 months. Serum samples were stored at $-20^{\circ} \mathrm{C}$.

\section{Bactericidal assay}

Serum bactericidal antibodies were measured as previously described (6). Briefly, the final reaction mixture contained $25 \mu \mathrm{L}$ diluted test serum previously heat inactivated at $56^{\circ} \mathrm{C}$ for $30 \mathrm{~min}, 12.5 \mu \mathrm{L}$ human serum that lacked detectable intrinsic bactericidal activity diluted at $1: 2$, and $12.5 \mu \mathrm{L}$ log phase meningococci (about $5 \times$ $10^{3}$ colony forming units $(\mathrm{CFU}) / \mathrm{mL}$ ) grown on Tryptic Soy Broth (Accumed, USA) solidified with $2 \%(\mathrm{w} / \mathrm{v})$ Noble agar (Merck, Germany) and containing 1\% (v/v) horse serum. The bactericidal reaction was carried out at $37^{\circ} \mathrm{C}$ for $30 \mathrm{~min}$. The CFU per well were determined with the aid of a stereoscopic microscope $(40 \times)$. The bactericidal titer was defined as the reciprocal of the serum dilution (before the addition of complement and bacteria) causing $\geqslant 50 \%$ killing and recorded as the $\log _{2}$ titer. A value of 1 was assigned to each titer of $<2$; thus, $\log _{2} 1=0$. The positive control for each assay consisted of a pool of postvaccination mouse serum with previously determined bactericidal titer. The negative control consisted of the complement source in the absence of test serum.

\section{Opsonic assay}

Latex bead coating with OMV, opsonization and phagocytosis were carried out as previously described (7). Briefly, the antigen-coated bead suspensions $(100 \mu \mathrm{L}$, $2.5 \times 10^{8}$ beads $/ \mathrm{mL}$ ) were opsonized for $8 \mathrm{~min}$ with $25 \mu \mathrm{L}$ diluted test serum (1:20) previously heat inactivated at $56^{\circ} \mathrm{C}$ for $30 \mathrm{~min}$, with a total sample volume of $400 \mu \mathrm{L}$ obtained by the addition of PBS-BSA, supplemented with $0.98 \mathrm{mM}$ $\mathrm{CaCl}_{2}$ and $1 \mathrm{mM} \mathrm{MgCl}$. Twenty-five microliters of human serum that lacked detectable intrinsic opsonization activity diluted at $1 \%$ was added to the reaction and incubated with end-to-end rotation for $8 \mathrm{~min}$ at $37^{\circ} \mathrm{C}$. Donor leukocytes $\left(100 \mu \mathrm{L}, 1.25 \times 10^{7} / \mathrm{mL}\right)$ were added and the suspensions were incubated for $8 \mathrm{~min}$. Phagocytosis was terminated by adding $1.5 \mathrm{~mL}$ ice-cold PBS supplemented with $0.02 \%$ EDTA. The suspensions were kept on ice until analysis with a FacsCalibur (BD Biosciences, USA) flow cytometer (7).

\section{Diphtheria toxin (DT) neutralization test}

The DT neutralization test in Vero cells (green monkey renal episerum) was used. The concentration of serum diphtheria antitoxin in cell culture was estimated according to the procedure described by Miyamura et al. (8), with some modifications. Serial 2-fold dilutions $(25 \mu \mathrm{L})$ of serum were mixed with $25 \mu \mathrm{L}$ DT equivalent to four times the minimal cytotoxic dose $(6.2 \mathrm{ng} / \mathrm{mL}$ ) (Sigma Aldrich, USA) and incubated for $1 \mathrm{~h}$ at $37^{\circ} \mathrm{C}$. Then, $50 \mu \mathrm{L}$ suspension containing $2.5 \times 10^{5}$ Vero cells $/ \mathrm{mL}$ in modified Eagle's medium supplemented with $10 \%$ fetal calf serum was added to each well. The plates were gently shaken, covered and incubated at $37^{\circ} \mathrm{C} / 5 \% \mathrm{CO}_{2}$ for 6 days. On the basis of concurrent testing with a reference serum (equine antiserum from Instituto Vital Brazil, Brazil; $1000 \mathrm{IU} / \mathrm{mL}$ antibody to DT), the antibody titer is reported as $\mathrm{IU} / \mathrm{mL}$. An antitoxin-positive control serum, a toxin control, a test serum control, and a cell control were run for every plate. Neutralizing antibody titer was defined as the highest dilution of serum neutralizing toxin that killed $100 \%$ Vero cells. Cell viability was determined by the MTT assay (9). Neutralizing antibody levels were categorized according to internationally accepted ranges: $<0.01 \mathrm{IU} / \mathrm{mL}$ (non-protective), 0.01 to $0.09 \mathrm{IU} / \mathrm{mL}$ (basic protection), and $\geqslant 0.1 \mathrm{IU} / \mathrm{mL}$ (full protection) $(10,11)$.

\section{Statistical analysis}

The levels of significance of the differences between groups were examined by the paired or unpaired $t$-test 
(parametric tests). For nonparametric data, either the Mann-Whitney test (unpaired samples) or the Wilcoxon matched-pair test (paired samples) was used. These analyses were performed with the GraphPad-Prism software, version 4.02 (GraphPad Software, Inc., USA). P < 0.05 was taken as significant.

\section{Results}

Kinetics of MenB antibody response to vaccine strain after immunization

Bactericidal antibody response. The bactericidal antibody response to the Cu385/83 strain was dosedependent (Figure 1A). After two doses there was approximately a 2-fold increase $(P>0.05)$ of bactericidal antibody titers $\left(\log _{2}\right.$ mean of $3.4,95 \% \mathrm{Cl}=$ 1.9-4.9) compared to the first dose $\left(\log _{2}\right.$ mean of 1.0 , $95 \% \mathrm{Cl}=-0.5-2.5)$. A continued increase (2-fold,

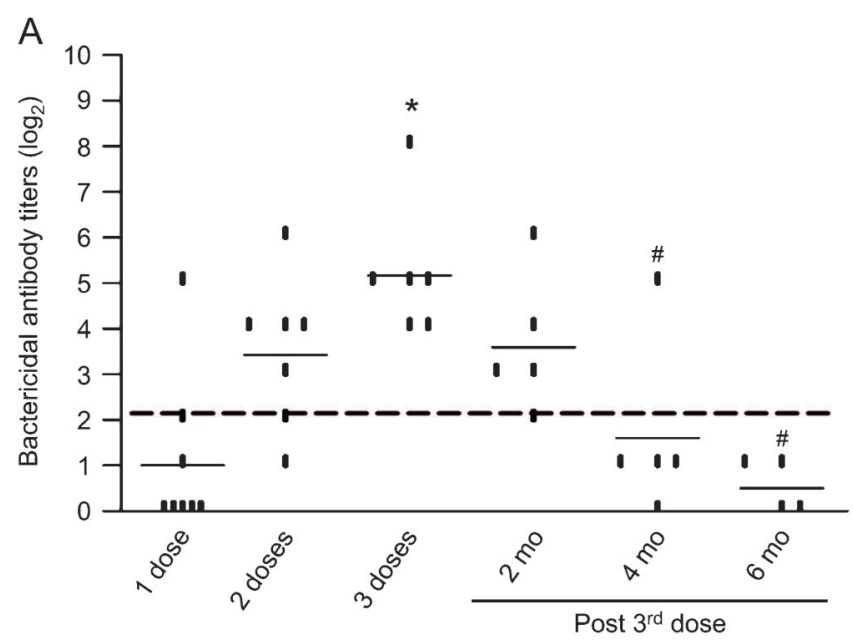

C

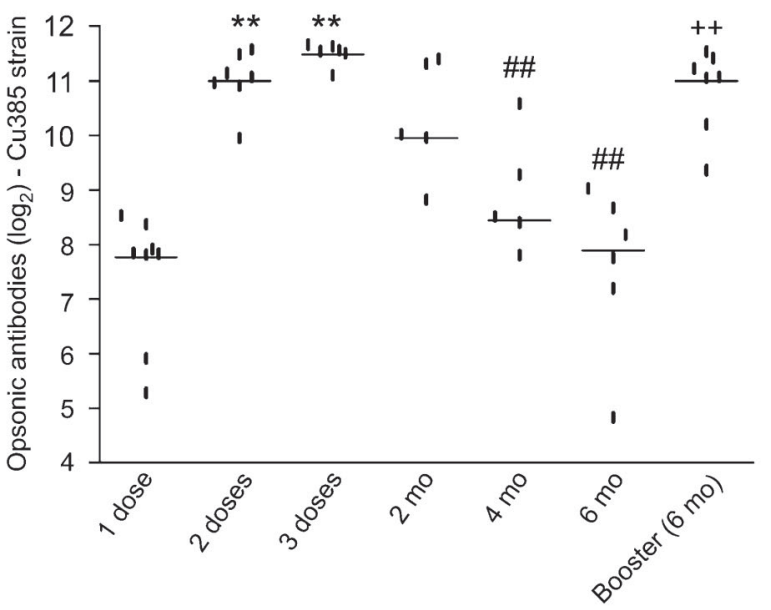

$P=0.02)$ of antibody titers was seen 14 days after three doses $\left(\log _{2}\right.$ mean of $\left.5.2,95 \% \mathrm{Cl}=3.6-6.7\right)$. After two doses of vaccine, only one individual (14\%) had antibody levels below $2\left(\log _{2}\right)$, but after three doses all subjects were considered to be protected against meningococcal disease ( $\log _{2}$ antibody titer $\geqslant 2$ ) (Figure 1A).

A gradual and significant decline of bactericidal antibody titers to MenB was recorded during the subsequent periods, ranging from 1.6 -fold at 2 months $\left(\log _{2}\right.$ mean of 3.6, $\mathrm{P}>$ 0.05 compared with 3 doses) to 3.6 -fold at 4 months $\left(\log _{2}\right.$ mean of 1.6, $P=0.03$ compared to 3 doses) and 4.7 -fold at 6 months $\left(\log _{2}\right.$ mean of $0.5, P=0.01$ compared to 3 doses; Figure 1A). Four months after the third dose, $80 \%$ of the animals had bactericidal titers below $2\left(\log _{2}\right)$ and 6 months later none had these antibody titers (Figure 1A).

The booster injections administered at 4 and 6 months, (Figure $1 \mathrm{~B})$ induced a significant $(P=0.006)$ increase in

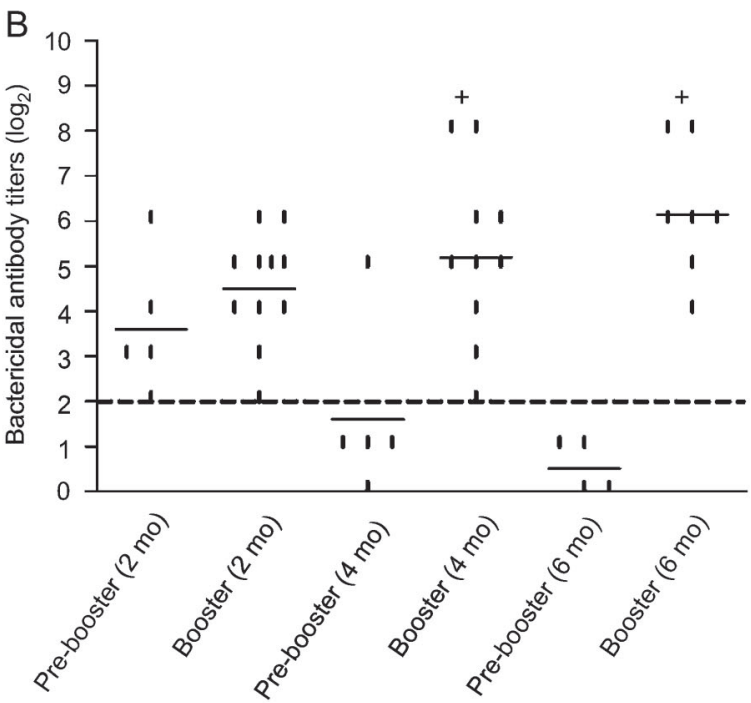

Figure 1. Bactericidal and opsonic antibody response to the MenB:4,7:P1.19,15 strain (Cu385/83) by mice immunized with VAMENGOC-BC ${ }^{\circledast}$. Lines show the average serum antibody titers $\left(\log _{2}\right)$ detected. $A$, Bactericidal antibodies at 14 days after each vaccine injection during the primary immunization schedule; $B$, bactericidal antibodies detected before (prebooster) and 14 days after booster injections given at 2,4 , and 6 months (mo) after the primary immunization schedule; $C$, opsonic antibodies at 14 days after each vaccine injection, at 2 , 4 , and 6 months post-third dose and at 14 days post-booster injection applied at 6 months. The dashed line in $A$ and $B$ represents the protective bactericidal titer ( 4 or $\log _{2}$ of 2 ). The points represent each individual antibody level, which was tested at least twice for each sample. ${ }^{*} \mathrm{P}<0.05$ compared to 1 and 2 doses. ${ }^{\#} \mathrm{P}<0.05$ compared to 3 doses. ${ }^{+} \mathrm{P}<0.05$ compared to pre-booster. ${ }^{* *} \mathrm{P}<0.05$ compared to 1 dose or 2 doses. ${ }^{\# \# P}<0.05$ compared to 3 doses. ${ }^{++} \mathrm{P}<0.05$ compared to pre-booster. The paired $t$-test was used for statistical analysis. 
bactericidal antibody levels to MenB $\left(\log _{2}\right.$ mean of 5.2 and 6.1 , respectively), reaching levels similar to those observed after the primary immunization ( $\log _{2}$ mean of 5.2). Since antibody titers were still high at 2 months ( $\log _{2}$ of 3.6) after the third dose, the booster injection at this time had little effect on antibody titers $\left(\log _{2}\right.$ mean of 4.5).

Opsonic antibody response. Figure $1 \mathrm{C}$ shows the opsonic antibody response to the MenB vaccine strain measured as the median fluorescence induced during the oxidative burst of neutrophils. A 3.6-fold increase $(P=$ $0.0007)$ in opsonic antibody levels was recorded after two doses ( $\log _{2}$ median of 11) when compared to the response induced by the first dose of VA-MENGOC-BC ${ }^{\circledR}$ $\left(\log _{2}\right.$ median $\log _{2}$ of 7.8). Compared to the second dose, the third injection of vaccine induced a small but significant $(P=0.04)$ increase of opsonic antibodies, with a $\log _{2}$ mean of 11.5 .

There was a significant $(P=0.007)$ decline of antibody concentrations recorded at 4 and 6 months after the third dose of MenB vaccine. This decline was smaller (1.2- to 3.9-fold) than the reduction of bactericidal antibody levels during the same period. After the booster dose $\left(\log _{2}\right.$ median of 11$)$ there was a significant $(P=$ 0.0007 ) increase of opsonic antibodies (3.2-fold; Figure 1C).

Bactericidal and opsonic antibodies to PorA and Opa mutants. To investigate the role of PorA and Opa proteins in the functional antibody titers, we used the H355 strain (PorA homologous to the vaccine strain) and its variants (PorA- and Opa- strains). As shown in Figure 2A, a substantial amount of bactericidal antibodies were directed at the PorA protein since we detected a significant decrease $(P=0.02)$ in antibody titers when the PorA ${ }^{-}$strain was used as the target strain compared with its parent $\mathrm{H} 355$ strain. The same was observed when bactericidal antibodies to the PorA ${ }^{-}$strain were compared to the Cu385 ( $P=0.04)$ and H355 Opa $(P=0.003)$ strains. Similar antibody titers were observed for Cu385, H355 and H355 Opa- strains.

The same picture was recorded for opsonic antibodies, with similar median antibody levels being found for both P1.19,15 strains (median of 2853 for Cu385 and 2189 for H355) (Figure 2B). Concerning the mutant strains, it was possible to clearly see a significant $(P<$ $0.0001)$ drop in opsonic antibody titers when the PorA ${ }^{-}$ (median of 542) but not when Opa- strain (median of $2295, \mathrm{P}>0.05$ ) was used as the target strain, compared to the H355 or Cu385 strains. This indicates a prominent role for PorA in inducing opsonic antibodies (Figure 2B).

Despite the high functional antibody levels detected after three doses of VA-MENGOC-BC ${ }^{\circledast}$, immunized mice were only partially protected (45.6\%) against the MenB challenge $\left(10^{5} \mathrm{CFU} / \mathrm{mL}, \mathrm{N} 44 / 89\right.$ strain) compared to saline controls $(20 \%)$, indicating the limitations of in vivo challenge experiments to predict protection from disease (data not shown).

\section{Kinetics of DT neutralizing antibody response to the DTP vaccine}

In contrast to previously published ELISA data (12), using the in vitro neutralization test we did not detect diphtheria antibodies before or after one injection of vaccine. However, as shown in Figure 3A, all animals had protective neutralizing antibody titers $(\geqslant 0.1 \mathrm{IU} / \mathrm{mL})$ after two doses of vaccine (mean of $1.84 \mathrm{IU} / \mathrm{mL}$ ) with a significant $(P=0.005)$ increase of antibodies after the

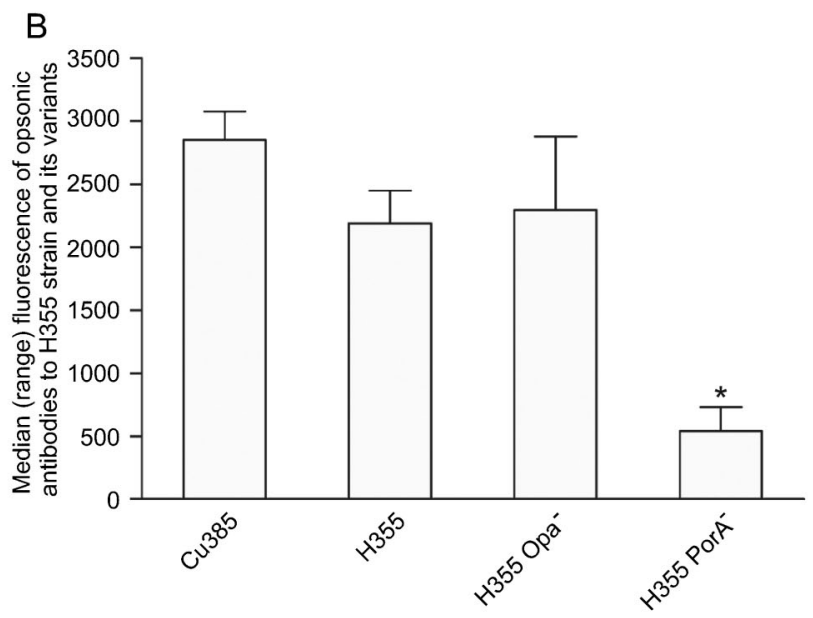

Figure 2. Bactericidal antibody titers $(A)$ and opsonic antibody response measured as median fluorescence induced during the oxidative burst of neutrophils $(B)$ to the vaccine strain Cu385/83, a P1.15,19 homologous strain (H355/75; $B: 15: P 1.19,15)$ and its variants Opa $^{-}$and PorA ${ }^{-}$. Serum samples were obtained 14 days after the third immunization. For bactericidal antibody titers $(A)$, the data are the mean \pm SE of three serum pools. Each pool contained serum from 3 individuals. For opsonic antibodies $(B)$, the data are the median and range of values of 6 mice. ${ }^{*} \mathrm{P}<0.05$ (Wilcoxon matched-pair test) compared to Cu385, $\mathrm{H} 355$ and to H355 Opa ${ }^{-}$strains. 

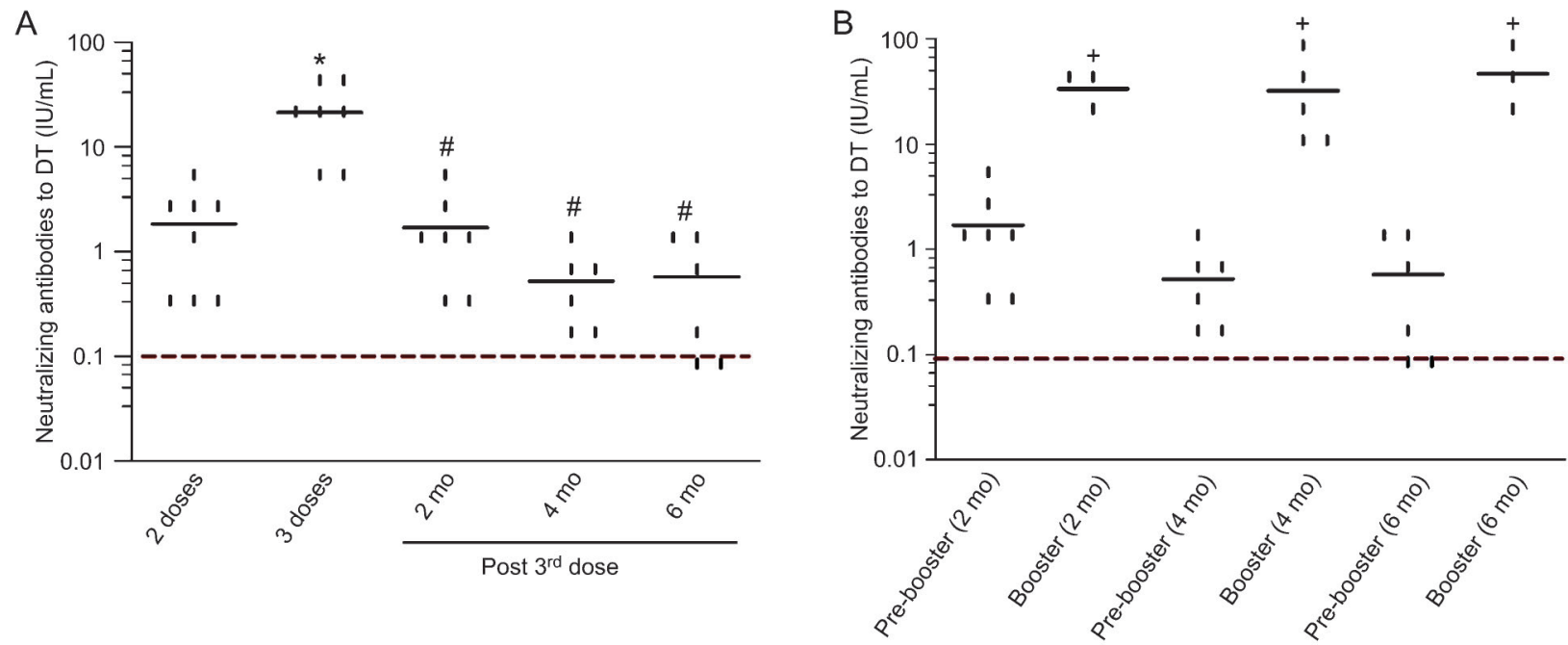

Figure 3. Neutralizing antibody levels to diphtheria toxoid (DT) of mice immunized with the diphtheria-tetanus-pertussis (DTP) vaccine. The lines show the average antibody titers detected at $(A) 14$ days after each vaccine injection during the primary immunization schedule and $(B)$ before (pre-booster) and 14 days after boosting at 2, 4, and 6 months (mo) after the primary immunization schedule. The dashed line in $A$ and $B$ represents the protective neutralizing antibody level $(>0.1 \mathrm{IU} / \mathrm{mL})$. Points represent each individual antibody level, which was tested at least twice for each sample. ${ }^{*} \mathrm{P}<0.05$ compared to 2 doses. ${ }^{\#} \mathrm{P}<0.05$ compared to 3 doses. ${ }^{+} \mathrm{P}<$ 0.05 compared to pre-booster. The paired $t$-test was used for statistical analysis.

third injection of DTP vaccine (mean of $21.2 \mathrm{IU} / \mathrm{mL}$ ). In fact, all individuals had antibody titers $>1 \mathrm{IU} / \mathrm{mL}$ after the third vaccination and were considered to be long-term protected. Antibody levels declined significantly $(P=$ 0.009) 2 months later (mean of $1.7 \mathrm{IU} / \mathrm{mL}$ ) and thereafter, ranging from 0.52 to $0.57 \mathrm{IU} / \mathrm{mL}$ at 4 and 6 months. However, antibody concentration remained above $0.1 \mathrm{IU} / \mathrm{mL}$ for all immunized mice until 4 months. At 6 months after the third dose, 2 animals (33\%) had a fall in neutralizing antibodies to levels conferring partial protection against diphtheria (0.01 to $0.09 \mathrm{lU} / \mathrm{mL})$.

The boosting antibody response was significant $(\mathrm{P}<$ $0.05)$ at all time points analyzed $(2,4$, and 6 months postprimary immunization) and were similar in magnitude (mean of 32 to $46.7 \mathrm{IU} / \mathrm{mL}$ ).

\section{Discussion}

For successful vaccines, primary vaccination elicits both protective immunity and memory. It is well known that immunological memory provides a swift and strong immune response upon re-exposure, as well as long-term protection even in individuals with very low and undetectable antibody levels (13). In general, immunity induced by MenB vaccines is of short duration, needing a boosting a few months after triple immunization to sustain significant antibody levels (14).

The Cuban MenB vaccine (VA-MENGOC-BC ${ }^{\circledR}$ ) employed in this study was previously used in Brazil to immunize millions of children but showed unsatisfactory efficacy (3). Since then, we have been studying the ability of this vaccine to generate and maintain immunological memory $(6,7,12)$.

The data presented here showed that the peak of bactericidal and opsonic antibody titers was reached after triple immunization with the MenB vaccine. The DT immunoglobulin response induced by the DTP vaccine also reached its maximum after three injections, with all animals reaching an antibody amount $>1 \mathrm{lU} / \mathrm{mL}$, a level considered to confer long-term protection against diphtheria (15). The lack of neutralizing antibodies after the first dose of vaccine may have been influenced by antibody avidity (13).

A significant amount of the bactericidal and opsonic antibodies induced by triple immunization was directed at the PorA protein. Since this protein can be absent or expressed at different levels and shows great antigenic variation, the search for alternative vaccine antigens should be stimulated (16). These data are similar to what we have seen in adults vaccinated with the Cuban MenB vaccine (7).

Four and 6 months after immunization, we observed that the decrease of antibody levels induced by the MenB vaccine was more marked compared to the fall of antibodies to DT. At 4 months after immunization with DTP vaccine, protective DT antibody levels were present in all DTP-vaccinated mice but only in $20 \%$ of mice immunized against MenB. After 6 months of primary immunization, about $70 \%$ of the animals still had protective neutralizing DT antibodies, but none had significant bactericidal antibodies to MenB. A long-lasting antibody-secreting cell response was also seen for the 
DTP vaccine compared to the Cuban MenB vaccine (12). The data presented here showed that the booster doses of DTP or MenB vaccines produced a significant functional antibody recall response, suggesting that both vaccines were able to generate memory $B$ cells in mice. A question remains about the duration of the memory response in humans. Adequate immunization against diphtheria consists of receiving 3 injections at 2, 4 and 6 months of age followed by booster doses every 10 years (17), but shorter booster intervals may be necessary for OMV vaccines against MenB (14).

According to studies with humans $(4,7)$, our data reported here indicate differences in the generation and maintenance of serological memory by the vaccines

\section{References}

1. Gossger N, Snape MD, Yu LM, Finn A, Bona G, Esposito S, et al. Immunogenicity and tolerability of recombinant serogroup B meningococcal vaccine administered with or without routine infant vaccinations according to different immunization schedules: a randomized controlled trial. JAMA 2012; 307: 573-582, doi: 10.1001/jama.2012.85.

2. Gorla MC, de Lemos AP, Quaresma M, Vilasboas R, Marques $O$, de Sá MU, et al. Phenotypic and molecular characterization of serogroup C Neisseria meningitidis associated with an outbreak in Bahia, Brazil. Enferm Infecc Microbiol Clin 2012; 30: 56-59, doi: 10.1016/j.eimc. 2011.07.022.

3. de Moraes JC, Perkins BA, Camargo MC, Hidalgo NT, Barbosa HA, Sacchi CT, et al. Protective efficacy of a serogroup B meningococcal vaccine in São Paulo, Brazil. Lancet 1992; 340: 1074-1078, doi: 10.1016/0140-6736(92) 93086-3.

4. Rosenqvist E, Hoiby EA, Wedege E, Bryn K, Kolberg J, Klem $A$, et al. Human antibody responses to meningococcal outer membrane antigens after three doses of the Norwegian group B meningococcal vaccine. Infect Immun 1995; 63: 4642-4652.

5. Bjune G, Hoiby EA, Gronnesby JK, Arnesen O, Fredriksen $\mathrm{JH}$, Halstensen $\mathrm{A}$, et al. Effect of outer membrane vesicle vaccine against group B meningococcal disease in Norway. Lancet 1991; 338: 1093-1096, doi: 10.1016/01406736(91)91961-S.

6. Gioia CA, de Sousa AB, Cruz SC, Junior FC, Andrade AF, Sassi RM, et al. Effect of a booster dose of serogroup B meningococcal vaccine on antibody response to Neisseria meningitidis in mice vaccinated with different immunization schedules. FEMS Immunol Med Microbiol 2005; 44: 35-42, doi: 10.1016/j.femsim.2004.11.013.

7. Cruz SC, Souza SL, Cruz AC, Silva GP, Milagres LG. Human antibody and memory $B$ and T-cell responses after primary and booster immunisation against Neisseria meningitidis B. Vaccine 2011; 29: 7387-7394, doi: 10.1016/j. vaccine.2011.07.072.

8. Miyamura K, Nishio S, Ito A, Murata R, Kono R. Micro cell culture method for determination of diphtheria toxin and antitoxin titres using VERO cells. I. Studies on factors under study. These differences may be related to the antigenic composition of the vaccines and suggest that, in contrast to the DTP vaccine, which is used in routine childhood immunization, the use of the VA-MENGOC-BC ${ }^{\circledR}$ vaccine should be limited to containing outbreaks of meningococcal disease.

\section{Acknowledgments}

We are grateful to Raphael Hirata Jr. and Ana Luiza de Mattos-Guaraldi, Universidade do Estado do Rio de Janeiro, for providing the diphtheria toxin and the reference anti-diphtheria toxin serum. We acknowledge FAPERJ, SR2-UERJ, CAPES, and CNPq for financial support. affecting the toxin and antitoxin titration. J Biol Stand 1974; 2: 189-201, doi: 10.1016/0092-1157(74)90015-8.

9. Efstratiou A, Engler KH, Dawes CS, Sesardic D. Comparison of phenotypic and genotypic methods for detection of diphtheria toxin among isolates of pathogenic corynebacteria. J Clin Microbiol 1998; 36: 3173-3177.

10. Ipsen $\mathrm{J} \mathrm{Jr}$.. Immunization of adults against diphtheria and tetanus. N Engl J Med 1954; 251: 459-466, doi: 10.1056/ NEJM195409162511202.

11. Orenstei WA, Weisfeld JS, Halsey NA. Diphtheria and tetanus toxoids and pertussis vaccine, combined. Publication No. 451. Washington: Pan American Health Organization, WHO; 1983.

12. Cruz SC, Silva GP, Sampaio FJ, Souza SL, Dias AA, Milagres LG. Comparison of long-term humoral memory development after immunisation against Neisseria meningitidis B or diphtheria toxoid. Vaccine 2010; 28: 6841-6846, doi: $10.1016 / j$.vaccine.2010.08.036.

13. Amanna IJ, Slifka MK. Contributions of humoral and cellular immunity to vaccine-induced protection in humans. Virology 2011; 411: 206-215, doi: 10.1016/j.virol.2010.12.016.

14. Feiring B, Fuglesang J, Oster P, Naess LM, Helland OS, Tilman $\mathrm{S}$, et al. Persisting immune responses indicating long-term protection after booster dose with meningococcal group B outer membrane vesicle vaccine. Clin Vaccine Immunol 2006; 13: 790-796, doi: 10.1128/CVI.00047-06.

15. Danilova E, Shiryayev A, Skogen V, Kristoffersen EK, Sjursen $\mathrm{H}$. Short-term booster effect of diphtheria toxoid in initially long-term protected individuals. Vaccine 2005; 23 : 1446-1450, doi: 10.1016/j.vaccine.2004.09.020.

16. de Filippis I, de Andrade CF, Silva L, Prevots DR, Vicente AC. PorA variable antigenic regions VR1, VR2, and VR3 of Neisseria meningitidis serogroups $\mathrm{B}$ and $\mathrm{C}$ isolated in Brazil from 1999 to 2004. Infect Immun 2007; 75: 3683-3685, doi: 10.1128/IAI.01721-06.

17. Ministério da Saúde/Fundação Nacional de Saúde. Comitê Técnico Assessor de Imunizações do Ministério da Saúde. Manual dos Centros de Referência de Imunobiológicos Especiais. 3rd edn. http://portal.saude.gov.br/portal/arquivos/ pdf/livro_cries_3ed.pdf. Accessed July 15, 2012. 